\title{
Physicochemical Properties of Two Fish Ponds in Akure, Implications for Artificial Fish Culture
}

\author{
Olukunle O. F, Oyewumi O. O
}

Department of Microbiology, the Federal University Of Technology, P M B 704 Akure Nigeria.

\begin{abstract}
The physicochemical analyses of water samples collected from Ponds located at the Department of Fisheries and Aquaculture, Federal University of Technology, Akure, FUTA and Pond in Oda Road, Akure were conducted using standard laboratory techniques.The values of the parameters ranged from $\mathrm{pH} 7.10 \pm 0.06^{b}$ $8.39 \pm 0.01^{c}$, conductivity $1.03 \pm 0.57^{c}-7.72 \pm 1.16^{b} \mathrm{mS} / \mathrm{cm}$, TDS $5.17 \pm 0.58^{c}-3.85 \pm 0.58^{b} \mathrm{mg} / \mathrm{l}$, turbidity $1.87 \pm 0.09^{c}-$ $0.60 \pm 0.06^{b}$ NTU, TSS $2.12 \pm 0.01^{c}-1.17 \pm 0.01^{b} \mathrm{mg} / \mathrm{l}$, BOD $12.60 \pm 0.06^{b}-12.63 \pm 0.09^{b} \mathrm{mg} / \mathrm{l}, \quad$ DO $\quad 62.77 \pm 0.03^{c}$ $41.67 \pm 0.01^{b} \mathrm{mg} / \mathrm{l}, \quad$ alkalinity $7.64 \pm 0.01^{b-} \quad 7.98 \pm 0.04^{b} \mathrm{mg} / \mathrm{l}$, sulphate $1.10 \pm 0.01^{a}-1.01 \pm 0.04^{a} \mathrm{mg} / \mathrm{l}, \quad$ phosphate $2.13 \pm 0.09^{b}-2.06 \pm 0.01^{b} \mathrm{mg} / \mathrm{l}$, nitrate $4.13 \pm 0.01^{c}$ $2.86 \pm 0.01^{b} \mathrm{mg} /$ l.However, there should be periodic or constantwater qualitycontrol of fish ponds in order to ensure conducive environment for fish safety. The physicochemical parameters investigated in this study, were within the range recommended for good fish production, indicating that the environmental conditions in these pond waters offer conducive conditions for fish survival and growth hence, increased productivity from fish ponds.
\end{abstract}

Keywords - Fish pond, Physicochemicals parameters, water samples.

\section{INTRODUCTION}

Pond ecosystems are often teaming with rich vegetation and a diverse organismal life. Pond is a body of fresh water smaller than a lake. Ponds are naturally formed by a depression on the ground filling and retaining water. Streams or spring water is usually fed into these bodies. They can also be man-made ponds which can be created by damming a stream, and digging a holes (Burnett, 2008). The bottom of a pond is usually sediment of sand, decaying matter and micro-organisms. Pond water is usually stagnant. Ponds have a wide variety of microbial life. Nutrients are brought to the pond by streams that feed into, run off during rain, or by the human anthrogenic activities (Ehiagbonare and Ogunrinde, 2010). The water in soil, animal waste and decaying plant matter in the pond are broken down and used to fuel the pond ecosystem. Many animals that live in the surrounding area, migrating birds and nearby plants depends on these ponds for a rich source of nutrient and water (Ehiagbonare and Ogunrinde, 2010).

Water quality refers to the chemical, physical, biological, and radiological characteristics of water (Diersing, 2009). Water quality describes the condition of the water, including chemical, physical, and biological characteristics, usually with respect to its suitability for a particular purpose such as drinking, swimming or to ascertain the suitability of such ponds water for artificial fish culture (Ayanwale et al., 2012). Physical factors that are important in domestic fish farming can be measured by several factors, such as the concentration of dissolved oxygen, bacteria levels, the amount of salt (or salinity), or the amount of material suspended in the water (turbidity). In some bodies of water, the concentration of microscopic algae and quantities of pesticides, herbicides, heavy metals, and other contaminants may also be measured to determine water quality(Ayanwale et al., 2012). Water quality generallymeans the component of water which must be present for optimum growth of aquatic organisms. The determinant of good growth in water body includes dissolved oxygen, hardness, turbidity, alkalinity, nutrients, temperature, etc. Conversely, other parameters like biological oxygen demand, and chemical oxygen demand indicate pollution level of a given water body. In most water bodies, various chemical parameters occur in low concentrations (Diersing, 2009).

According to Burnett (2008), ponds have an average of 184.5 different types of microbes. There are many factors that determine the variety and number of organisms that live in a pond. These factors include oxygen, light, size, shelter and competition for food and nutrients. Quality of pond water could be detected through physico-chemical and microbial analysis so that people could be aware of its use for different purposes.The present study therefore investigate the physicochemical parameter of two selected pond water. 


\section{METHODOLOGY}

Study Area

This study was carried out in ponds in Ijigba layout, off Oda road and Federal University of Technology both in Akure, Ondo State, Nigeria. Ijigba layout lies between latitudes $7.2^{\circ}$ North and longitude $5.2^{\circ}$ East. Federal University of
Technology, Akure (FUTA) lies between longitude 5.1 East and latitude $7.2^{\circ}$ North. Operations such as integrated fish pond production having both concrete and earthen fish ponds stocked with tilapia fish and catfish are been performed in these ponds.

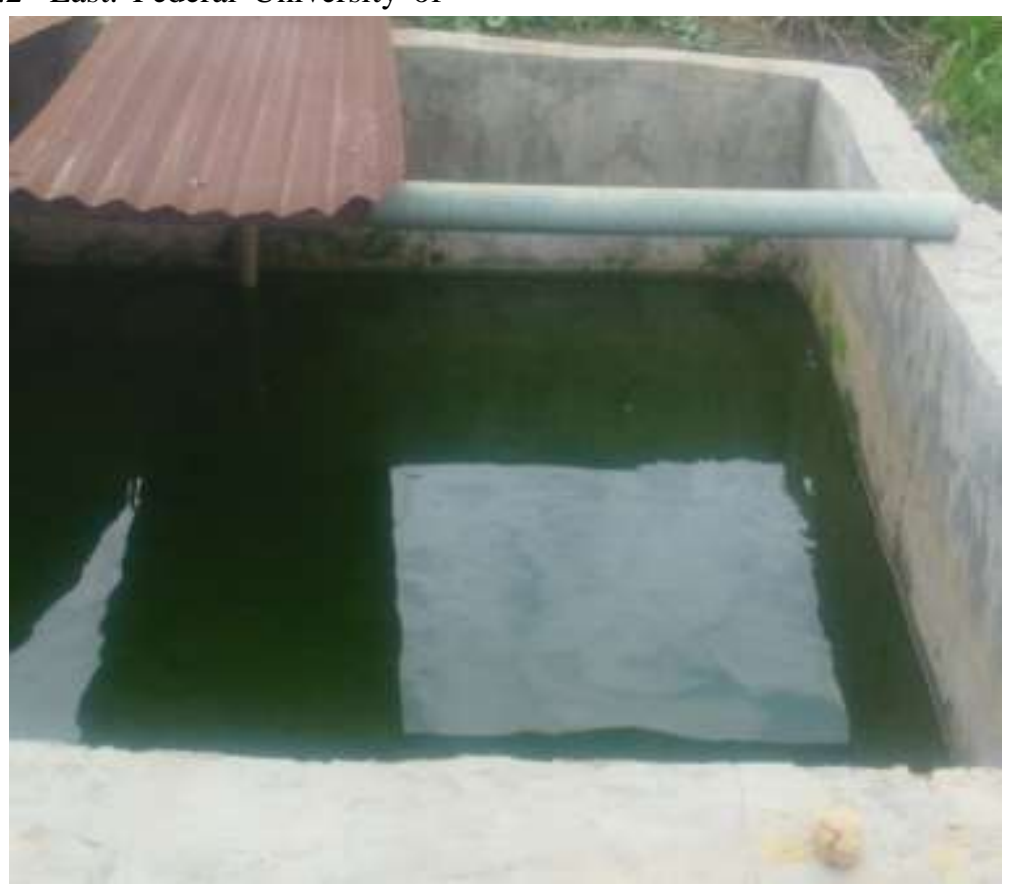

Plate.1: Oda Road Pond

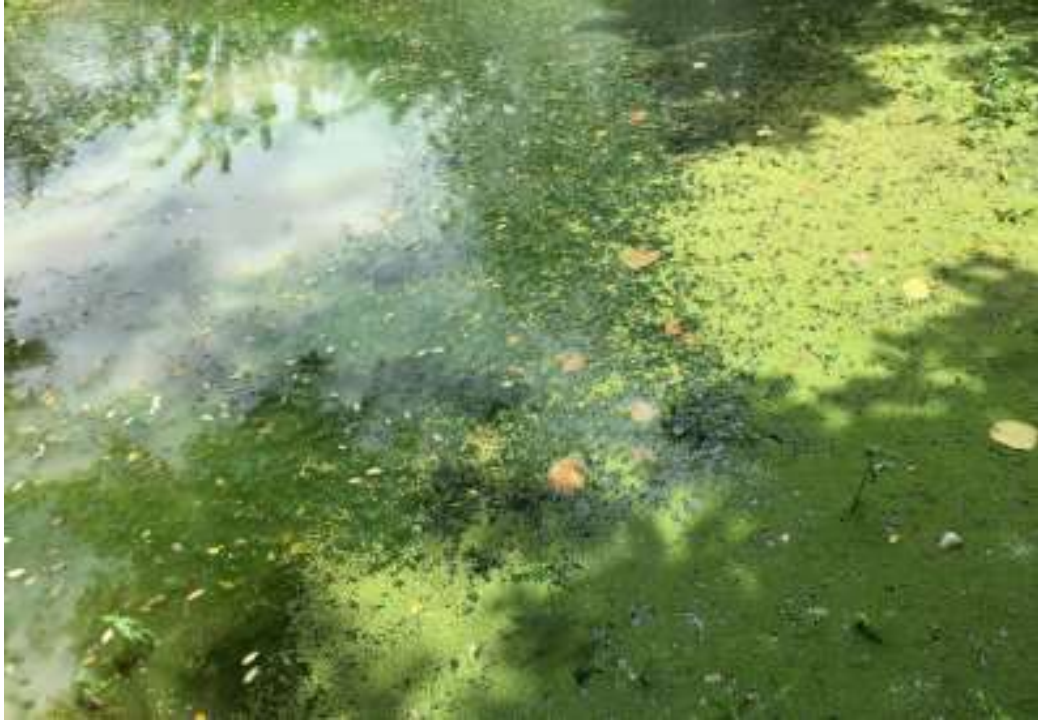

Plate.2: FUTA Fish Pond

\section{Collection of Fresh Water Samples}

Water samples were collected aseptically from ponds water surface using sterile cap bottles. The water samples were transported to the laboratory, FUTA in an ice packed container for physico-chemical analyses.

Analysis of Water Quality in Pond Using PhysicoChemical Parameters 
Test for $\mathrm{pH}$

This test was carried out to determine the hydrogen ion concentration in the pond water sample. The $\mathrm{pH}$ was determined using a $\mathrm{pH}$ meter (Suntex model sp-701), which was first calibrated with buffer 4 and 7 (using $1 \mathrm{M} \mathrm{NaOH}$ and $1 \mathrm{M} \mathrm{HCL}$ ). The probe of the $\mathrm{pH}$ meter was rinsed with distilled water. Samples of $20 \mathrm{ml}$ of pond water were measured in a labeled beakers, then the probe was inserted into the sample collected. The reading was taken when the $\mathrm{pH}$ meter displayed a stable value. The probe was rinsed with distilled water and cleaned with tissue paper after each insertion in the various samples (Ehiagbonare and Ogunrinde, 2010).

\section{Test for Turbidity}

This test was carried out to measure the degree to which water loses its transparency due to the presence of suspended solid particles. The turbidity was determined using a turbidometer (Nach model 2100N). The turbidometer was turned on to initialize. The cuvette of the meter was rinsed with distilled water, and $10 \mathrm{ml}$ of distilled water was dispensed into the cuvette then placed in the meter to calibrate it and later poured off. After the meter had been calibrated, $10 \mathrm{~mL}$ of pond water samples was dispensed in the cuvette and placed in the turbidometer (Nach model $2100 \mathrm{~N}$ ) at a wavelength of $810 \mathrm{~nm}$. Readings were taken and recorded in units known as Formation Turbidity Unit (FTU) (Ademoroti, 1996).

\section{Test for Conductivity and Total dissolved Solid (TDS)}

This test was carried out to determine the concentration of the dissolved mineral salt and to determine the ionic effect in water sample. The conductivity was determined using conductivity meter (Labtech model 648). Pond water samples of $20 \mathrm{ml}$ was measured and dispensed into the labeled beakers. The meter was switched on and its probe rinsed with de-ionized water, and the probe was inserted into the pond water samples, and the read button was pressed on the meter to take the readings. The unit is $\mu \mathrm{s} / \mathrm{cm}$ (micro Siemens per $\mathrm{cm}$ ) and the total dissolve solid (TDS) ions such as potassium, sodium, chloride, carbonate, sulfate, calcium, and magnesium that contribute to the dissolved solids in water were determined using the formular: TDS = $0.5 \times$ Conductivity (Ehiagbonare and Ogunrinde, 2010).

Test for Total Suspended Solid (TSS) and Total Solid (TS)

This test was carried out to determine the concentration of suspended solid particles in pond water samples, it basically refers to matter suspended or dissolved in water. Beakers was rinsed and labeled, then pond water samples was homogenized with industrial blender which was later poured into the labeled beakers. Ten (10) $\mathrm{ml}$ of homogenized pond water sample in the beaker was dispensed into the cuvette and placed in the spectrophotometer (Hach 3900). Readings were taken and recorded; the unit of measurement is $\mathrm{mg} / \mathrm{l}$. Total solid test was conducted to determine the concentration of both suspended and dissolved solids in pond water samples. The formular used was: TS $=$ TSS + TDS (Ehiagbonare and Ogunrinde, 2010).

\section{Dissolved Oxygen (DO)}

This was carried out to determine the amount of oxygen present in water. Two (2) $\mathrm{ml}$ of manganese sulphate and $2 \mathrm{ml}$ of alkali iodide azide reagent were added to the $20 \mathrm{ml}$ of pond water measured and a brownish colour was obtained. The solution was then made to stand until it formed clear supernatants and concentrated sulphuric acid was added for preservative purpose and was shaken to distribute iodide evenly. Sodium thiosulfate was used in titrating to get a pale yellow and $1 \mathrm{ml}$ of $1 \%$ starch was added to get blue-black colour. At a point, the blue-black colour disappeared which is referred to or known as the end point. (Ehiagbonare and Ogunrinde, 2010).

\section{Biological Oxygen Demand (BOD)}

Water samples were aerated for five days at $20^{\circ} \mathrm{C}$ in an incubator in a BOD bottle with a volume of $355 \mathrm{ml}$ and 105 $\mathrm{ml}$ volume of the samples was used. Distilled water was used as water solution for dilution and as a blank which were aerated for five days using clean supply of compressed air, later the dissolved oxygen (DO) was then taken after five days of incubation and the BOD was determined using the mathematical formula below:

BOD $(\mathrm{mg} / \mathrm{l})=\mathrm{DO}_{\mathrm{o}}-\mathrm{DO}_{\mathrm{d}}, \mathrm{DO}_{\mathrm{o}}=$ dissolved oxygen of the first day, $\mathrm{DO}_{\mathrm{d}}=$ dissolved oxygen after five days (Ehiagbonare and Ogunrinde, 2010).

Test for Sulphate, Nitrate, and Phosphate using Colorimetric Method

Sulphate was determined using colorimetric method where $25 \mathrm{ml}$ of each sample was measured in a Nessier tube; $25 \mathrm{ml}$ of Barium chloride was added. The solution, which gave various colours, was allowed to stand for 15 minutes and its turbidity was measured at a wavelength of $420 \mathrm{~nm}$ in a spectrophotometer. Nitrate was determined by measuring 10 $\mathrm{ml}$ of the sample into a Nessier tube and the same amount of distilled water was measured into a Nessier tube, $0.5 \mathrm{~mL}$ of brucine and $20 \mathrm{~mL}$ of concentrated sulphric acid was added to each, thereafter the turbidity of colour produced by each tube was measured using a spectrophotometer (Hach 3900 ) at a wavelength of $470 \mathrm{~nm}$ (Ehiagbonare and Ogunrinde, 2010). Phosphate were measured using Nessler 
reaction and Ascorbic acid method respectively (Njoku et al., 2015)

\section{RESULTS}

\section{Physicochemical Analysis of Pond waters}

The results for the physicochemical analysis $(\mathrm{pH}$, Conductivity, Turbidity, TSS, TDS, TS, BOD, DO, Nitrate, Sulphate, Phosphate) of the pond waters are shown in Table

1. The Oda Road pond has a lower conductivity value of $1.03 \mathrm{~ms} / \mathrm{cm}$, andhigher value of dissolved oxygen (DO) $62.77 \mathrm{~ms} / \mathrm{cm}$ while FUTA pond had a lower turbidity value of 0.60 NTU.

Table.1: Physicochemical Parameters of Pond waters

\begin{tabular}{lll} 
Parameters & Oda Road Pond & FUTA Pond \\
\hline Temperature & $26.80 \pm 0.06^{\mathrm{b}}$ & $28.40 \pm 0.12^{\mathrm{b}}$ \\
pH & $7.10 \pm 0.06^{\mathrm{b}}$ & $8.39 \pm 0.01^{\mathrm{c}}$ \\
Conductivity & $1.03 \pm 0.57^{\mathrm{c}}$ & $7.72 \pm 1.16^{\mathrm{b}}$ \\
ms/cm & & \\
Turbidity (NTU) & $1.87 \pm 0.09^{\mathrm{c}}$ & $0.60 \pm 0.06^{\mathrm{b}}$ \\
Alkalinity (mg/l) & $7.64 \pm 0.01^{\mathrm{b}}$ & $7.98 \pm 0.04^{\mathrm{b}}$ \\
TSS (mg/l) & $2.12 \pm 0.01^{\mathrm{c}}$ & $1.17 \pm 0.01^{\mathrm{b}}$ \\
TDS (mg/l) & $5.17 \pm 0.58^{\mathrm{c}}$ & $3.85 \pm 0.58^{\mathrm{b}}$ \\
TS (mg/l) & $5.19 \pm 0.58^{\mathrm{c}}$ & $3.88 \pm 1.16^{\mathrm{b}}$ \\
BOD (mg/l) & $12.60 \pm 0.06^{\mathrm{b}}$ & $12.63 \pm 0.09^{\mathrm{b}}$ \\
DO (mg/l) & $62.77 \pm 0.03^{\mathrm{c}}$ & $41.67 \pm 0.01^{\mathrm{b}}$ \\
Nitrate (mg/l) & $4.13 \pm 0.01^{\mathrm{c}}$ & $2.86 \pm 0.01^{\mathrm{b}}$ \\
Sulphate (mg/l) & $1.10 \pm 0.01^{\mathrm{a}}$ & $1.01 \pm 0.04^{\mathrm{a}}$ \\
Phosphate (mg/l) & $2.13 \pm 0.09^{\mathrm{b}}$ & $2.06 \pm 0.01^{\mathrm{b}}$ \\
\hline
\end{tabular}

Data along the same row are not significantly the same

\section{DISCUSSION}

The $\mathrm{pH}$ is a major factor that determines the growth of microorganisms. The $\mathrm{pH}$ measurement helps to determine if the water is a proper environment for fish, plants and algae. The $\mathrm{pH}$ obtained from both ponds in this study were within the range of $\mathrm{pH} 7.0$ to 10.0 required for aquaculture as reported by Njoku et al. (2015). Ehiagbonare and Ogunrinde (2010), and Kamal et al. (2007).

The temperature obtained from this study ranged from $26^{\circ} \mathrm{C}$ $-29^{\circ} \mathrm{C}$ which is still within the limit that supports fish productivity. Ntegwu and Edema (2008) has reported optimum temperature $20^{\circ} \mathrm{C}-30^{\circ} \mathrm{C}$ for increased fish productivity. This finding corroborates the report of Fafioye (2011) who observed a temperature of $27^{\circ} \mathrm{C}-28^{\circ} \mathrm{C}$ in the preliminary studies and water characteristic of microbial population in Kojalo fish pond.

The results of conductivity from this study ranged from $1.03 \pm 0.57 \mu \mathrm{s} / \mathrm{cm}$ to $7.72 \pm 1.16 \mu \mathrm{s} / \mathrm{cm}$. Higher conductivities $(\mu \mathrm{s} / \mathrm{cm})$ of water were observed in FUTA Pond which might be due to discharge of pollutants into the pond water.. The FAO acceptable limit for conductivity in aquaculture is between 20 and $1500 \mu \mathrm{s} / \mathrm{cm}$ (DWAF, 1996). This limit was not exceeded in the ponds studied. Thus, the parameter is suitable for fish production. However, the result is in contrast to the findings of Ehiagbonare and Ogunrinde (2010) who reported conductivity value of 0.012 $\mu \mathrm{s} / \mathrm{cm}-0.017 \mu \mathrm{s} / \mathrm{cm}$ for fish pond water in Okada and its environs.

It was observed that the turbidity values obtained from the FUTA pond and Oda Road pond were 0.60NTU and $1.87 \mathrm{NTU}$ respectively. Turbidity hinders the penetration of sunlight in the pond making it difficult for aquatic habitat such as algae that require light for photosynthesis to receive the positive effect of light (Ali et al., 2004). However, the results of turbidity obtained from this study, is in contrast to the findings of Ehiagbonare and Ogunrinde (2010) who reported higher turbidity value of 5NTU - 170NTU.

The BOD obtained from Oda Road pond and FUTA pond were $12.60 \mathrm{mg} / \mathrm{l}$ and $12.63 \mathrm{mg} / \mathrm{l}$ respectively. The BOD obtained from this study was higher than the findings of Ehiagbonare and Ogurinde (2010) who reported BOD of $3.38 \mathrm{mg} / \mathrm{l}$ in Oloku and $2.4 \mathrm{mg} / \mathrm{l}$ in concrete ponds in Igusa and $1.6 \mathrm{mg} / \mathrm{l}$ in earthen pond at Afugle during the study of physiochemical analysis of pond water in Okada and its environs. The increase in BOD might be due to excreta of the fish, feed use or high organic matter (Kay et al., 2008). However, these values are below the BOD standard of 30 $\mathrm{mg} / \mathrm{l}$ recommended by the Federal Environmental Protection Agency, FEPA (FEPA, 1991). This implies that the pond water is devoid of pollution and the fishes are not affected negatively.

The dissolved oxygen (DO), obtained in this study ranged from $41.67 \mathrm{mg} / 1$ to $62.77 \mathrm{mg} / 1$. The result obtained from this study is higher than the result obtained by Onome and Ebinimi, (2010) who reported DO of $4.34 \mathrm{mg} / \mathrm{l}$ and $6.33 \mathrm{mg} / \mathrm{l}$ from the surrounding industries near fish farm, and Ehiagbonare and Ogunrinde (2010) who reported DO value of $9.3 \mathrm{mg} / \mathrm{l}-16.2 \mathrm{mg} / \mathrm{l}$. The high value of dissolved oxygen recorded in study could be attributed to elevated temperature, increased microbial and organic loads and resultant increase in metabolic activity (FAO, 2005). Similar findings was also reported by Okpokwasili and Ubah, (1991) on water quality and bacterial disease in fish pond. However, Saloom and Duncan, (2005) suggested that the minimum DO should be $5 \mathrm{mg} / \mathrm{l}$ for tropical fish.

The alkalinity values obtained from Oda Road Pond and FUTA pond were $7.64 \mathrm{mg} / 1$ to $7.98 \mathrm{mg} / 1$ respectively. 
Ehiagbonare and Ogunrinde (2010) reported alkalinity values of between $35 \mathrm{mg} / \mathrm{l}$ and $135 \mathrm{mg} / \mathrm{l}$ for fish pond water. Njoku et al. (2015) on the other hand, reported alkalinity values of between $200 \mathrm{mg} / \mathrm{l}$ and $290 \mathrm{mg} / \mathrm{l}$ in concrete pond and between $18 \mathrm{mg} / \mathrm{l}$ and $24 \mathrm{mg} / \mathrm{l}$ in earthen pond. $\mathrm{He}$ suggested the optimum alkalinity for increased fish production is between $20 \mathrm{mg} / \mathrm{l}$ and $300 \mathrm{mg} / \mathrm{l}$. The reason for the variations in the alkalinity values might be due to high limestone in the fish pond water.

Findings from the result of nitrate concentration obtained in this research work ranged from $2.86 \mathrm{mg} / 1$ to $4.13 \mathrm{mg} / \mathrm{l}$ and was lower than the maximum permissible limit of $10 \mathrm{mg} / \mathrm{l}$. The low concentration of nitrate might be due to absence of eutrophication. However, this findings corroborate the findings of Ehiagbonare and Ogunrinde (2010) who reported nitrate value of between $2.21 \mathrm{mg} / \mathrm{l}$ and $4.91 \mathrm{mg} / \mathrm{l}$. Eze and Ogbaran (2010) observed that nitrate is a skin irritant and will cause the fish to display symptoms of irritability such as rubbing themselves, jumping and skimming across the surface of the pond. High nitrate value concentration causes algal bloom while nitrate deprivation leads to increased lipid content in algae and in turn affect the water ecosystem. Furthermore, Dourborow et al. (1997) stated that high concentration of nitrate prevents the blood cells from absorbing oxygen from water and this process turns their blood to a dull brown color and hence the popular name of nitrite poisoning "brown blood disease".

It was revealed from this findings, that the phosphate level in FUTA pond and Oda Road pond was below the $3 \mathrm{mg} / \mathrm{l}$ standard. However, this findings is in agreement with the work of Ehiagbonare and Ogunrinde (2010) who reported phosphate values of between $1.40 \mathrm{mg} / 1$ and $4.51 \mathrm{mg} / \mathrm{l}$. This low values of phosphate may be due to the type of fish feed introduced into the pond or surface run off, and could also be from the building materials used in the construction of the ponds. According to Durborow et al. (1997), high concentration of phosphate may cause algal bloom leading to killing of fishes in the pond. Also, Eze and Okpokwasili (2010) stated in their findings that this limit should be controlled to avoid eutrophication of the ponds. These fishes can also store phosphate in their organs and when they die, they release the previously absorbed Phosphate into the water which triggers the growth of new algae and create algal bloom or eutrophication.

The result of sulphate concentration in the ponds from this study varied from 1.01 to $1.10(\mathrm{mg} / \mathrm{l})$ with the Oda Road pond higher than the FUTA pond. The result obtained from this study was similar to the findings of Ehiagbonare and Ogunrinde (2010) who reported sulphate concentration of between 0.66 and $1.09 \mathrm{~m} / \mathrm{l}$. However, Utang and Akpan (2012) had reported sulphate concentration of 42.46 and $57.36 \mathrm{mg} / \mathrm{l}$. Sulphate that leach from soil fertilized with animal manure which got into the water body may be responsible for the high value of sulphate (Ehiagbonare and Ogunrinde (2010).

\section{CONCLUSION}

Analysing water is an important part of environmental monitoring which is essential part of keeping the planet healthy and sustainable. When water quality is poor, it affects not only aquatic life but the surrounding ecosystem as well which were carried out in this study. Findings from this work revealed that regularly monitoring water parameter such as temperature, $\mathrm{pH}$ etc provide insight to the health of the aquatic ecosystems. The results may be used to pinpoint any changes or trends that appear in water bodies over a period of time.Conclusively, as we continue to build cities, clear land for farming such as aquaculture and make other man-made changes to the natural environment, water quality monitoring should be done to ensure good functioning of the aquatic ecosystem increased fish productivity.

\section{ACKNOWLEDGEMENTS}

The authors are grateful to Department of Microbiology, School of Sciences, Federal University of Technology, Akure, Ondo State, Nigeria for providing reagents and space.

\section{COMPETING INTERESTS}

Authors have declared that no competing interests exist.

\section{REFERENCES}

[1] Ademoroti, C. M. A. (1996). Standard Methods for Water and Effluents Analysis. Foludex Press, Ibadan. pp. 28-76.

[2] Ali, F. M, Abdus-Salam, B. A., Ahmad, K. S., Qamar, M. and Umer, K. (2004). Seasonal Variations of Physico - Chemical Characteristics of River Soan Water at Dhoak Pathan Bridge (Chakwal), Pak. 1: 89 - 92.

[3] Aullon, A. A. (2010). Biodiesel from Microalgae. Journal of Chemical Engineering and Technology, 192.

[4] Ayanwale, A. V., Minnin, M. A., Olayemi, K. I. (2012). Physico-chemical Properties of Selected Fish Ponds In Nigeria: Implications for Artificial Fish Culture. WebmedCentral Biology Journal. 3(10): 975 
[5] Burnett, C. (2008).Where Do Microbes Lives? Mercer University.ppp 3 Retrieved August, 2016

[6] Durbrow, R. (2000). Catfish Farming in Kentucky. State University of Aquaculture Programme Kentucky Department of Aquaculture and Natural Oceanic and Atmospheric Administration. P.18-21.

[7] Diersing, N. (2009). Water Quality: Frequently Asked Questions."Florida Brooks National Marine Sanctuary, Key West, FL. Pg 1.8

[8] DWAF, (1996).South African Water Quality Guidelines. Domestic Uses 2nd (ed). Department of Water Affairs and Forestry - Pretoria, 1. P.53.

[9] Ehiagbonare, J. E., Ogunrinde, Y. O. (2010). Physicochemical Analysis of Fish Pond in Okada and its Environs. Nigeria, African Journal of Biotechnology, 36: 5922 - 5928.

[10] Eze, V. R. and Okpokwasili, G. C. (2010). Ecodynamics of Exchangeable Cations and Anion Pollutants of a Niger, Delta River Sediment Receiving Industrial Effluent. ContinentalJournal of Environmental Science, 4: 36 -43.

[11]Eze, V.C. and Ogbaran, I. O. (2010). Microbiological and Physicochemical Characteristic of Fish Pond Water in Ughelli, Delta State, Nigeria. International Journal of Current Research, 8: 082087.

[12] Fafioye, O. O. (2011) .Preliminary Studies on Water Characteristics and Bacterial Population in High Yield Kajola Fish Ponds. Journal of Agriculture Extension and RuralDevelopment, 3: $68-71$

[13] FAO (2005). The State of World Fisheries and Aquaculture. FAO. United Nations Rome. Food control, 18:1391-1396.

[14] FEPA Guidelines and Standard for Environmental Pollution Control in Nigeria (1999). Pp 200.

[15] Houghton, T. P., Stevens, D. M., Pryfogle, P. A., Wright, C. T., and Radtke, C. W. (2009). The Effect of Drying Temperature on the Composition of Biomass. Applied Biochemistry and Biotechnology, 153: 4-10.

[16] Kay, D., Crowther, J., Stapleton, C.M., Wyer, M.D., Ewtrell, L.F., Edwards, A., Francis, C.A. McDonald, A.T. Watkinson, J. (2008). Fecal Indicator Organism Concentrations in Sewage and Treated Effluents. Water Resources, 42:442-445.

[17] Njoku, O. E., Agwa, O.K. and Ibiene, A. A. (2015). An Investigation of the Microbiological and Physicochemical Profile of Some Fish Pond Water within the Niger Delta Region of Nigeria. European Journal of Food Science and Technology, 3: 20-31.

[18] Ntengwe, F. N. and Edema, M. O. (2008). Physicochemical and Microbiological Characteristics of Water for Fish Production using Small Ponds. Physics and Chemistry ofEarth. 33:701-707.

[19] Okpokwasil, G. C. and Ubah, O. O. (1991). Relationship Between Water Quality and Bacteria Associated with the Brown Patch Disease of Tilapia Fingerlings Reared in Tropical. Fish Water Culture Ponds. Journal of Aquaculture Tropical 6: 157- 172.

[20] Onome, A. D. and Ebinimi, A. (2010). Comparative Assessment of Water Quality Parameters of Fresh Water Tidal Earthen and Stagnant Concrete Tanks for Fish Production in Port Harcourt, Nigeria. International Journal of Science and Nature, 11: 3437.

[21] Saloom, M. E., and Duncan, R. S. (2005). Low dissolved oxygen levels reduce anti- predator behaviours of the fresh water Clam Corbicula fluminea. Fresh Water Biologyjournal. 50: 1233-1238.

[22] Utang, P. B. and Akpan, E. H. (2012). Water quality Impediments to Sustainable Aquaculture Development along Selected Segments of the New Calabar River, Niger Delta, Nigeria. Research Journal Environmental and Earth Science, 1: 34-40.

[23] Van, T. D., Yan, Li., Ekaterina, N. and Peer, M. (2012). Microalgae Isolation and Selection for Prospective Biodiesel Production. Energies, 5: 18351849. 